\title{
Iceland's External Affairs from 1550-1815: Danish societal and political cover con- current with a highly costly economic policy
}

\author{
Baldur Pórhallsson, Professor of Political Science, University of Iceland \\ Tómas Joensen, Researcher, University of Iceland
}

\begin{abstract}
The paper argues that there is not necessarily a correlation between political, economic and societal shelter. Iceland received considerable societal and political shelter from Denmark in the period under study, but Denmark failed to provide its remote island with economic cover. Firstly, and most importantly, it provided substantial and highly valuable societal shelter. Copenhagen was the main channel by which new knowledge and technology could enter Iceland. The islanders benefited from educational, health-care and social policies of the crown and it played an invaluable role in preserving Iceland's cultural heritage. Secondly, Denmark provided partial protection of Icelandic waters and land though Iceland's peripheral position continued to be its main protection from outside attacks. However, at the end of our period, the Danish kingdom was in decline and unable to provide political cover. Nevertheless, increased centralization, initiated from Denmark, provided internal order and political stability and citizens became more equal before the law. Thirdly, Icelanders paid a heavy price for the Danish trade monopoly though Icelanders continued to receive partial economic and societal shelter from foreign merchants and fishermen. The crown's policies towards Iceland can largely be explained by current ideological trends at any given time. By being in constant contact with the European continent through Denmark, Icelandic society was part of the
\end{abstract}

Icelandic Review of Politics and Administration Vol 10, Issue 2(189-214)

(C) 2014 Contacts: Baldur Pórhallsson, baldurt@hi.is and Tómas Joensen toj@hi.is

Article first published online December 18th 2014 on http://www.irpa.is

Publisher: Institute of Public Administration and Politics, Gimli, Sæmundargötu 1, 101 Reykjavík, Iceland

Stjórnmál \& stjórnsýsla 2. tbl. 10. árg. 2014 (189-214)Fræđigreinar

C 2014 Tengiliðir: Baldur Pórhallsson, baldurt@hi.is og Tómas Joensen toj@hi.is

Vefbirting 18. desember 2014 - Birtist á vefnum http://www.irpa.is

Útgefandi: Stofnun stjórnsýslufræđa og stjórnmála, Gimli, Sæmundargötu 1, 101 Reykjavík

DOI: http://dx.doi.org/10.13177/irpa.a.2014.10.2.2

This work is licensed under Creative Commons Attribution 3.0 License 


\section{STJÓRNSÝSLA}

societal, political and economic evolution in Europe and managed to avoid isolation despite its geographical remoteness.

Keywords: Iceland; small states; international relations; shelter, economy; culture; politics; Denmark.

\section{Introduction}

This paper is the third ${ }^{1}$ in a 'hexalogy' (a series of six) that examines Iceland's foreign relations from the time of the Settlement up to the present day, using the shelter theory as its theoretical standpoint. The previous two papers have examined 'the Norwegian Period', from the Settlement up to 1400 and 'the English and German Periods', from about 1400 up to the Reformation in the mid-16 $6^{\text {th }}$ century, respectively (see Pórhallsson 2012; Pórhallsson and Kristinsson 2013). This paper will cover the first half of the Danish period, i.e. from the Reformation until 1815, when the Danish kingdom lay in ruins after being on the losing side in the Napoleonic wars.

We want to emphasize that this project is not an independent primary research of Icelandic history as such. Research in that field, already made, is used in the framework of a sociological theory, the shelter theory, which is explained in the following chapter. Our ambition is the investigation of how present historical facts fit into this theory. The core objective is to examine Iceland's position within the international system through the ages and analyse its external affairs as part of events taking place in the world, rather than as an isolated, domestic, phenomenon. Thus, the aim is not to rewrite the history of Iceland but to analyse it from a different perspective and open up a debate that could stimulate further research on the importance of foreign relations for small and peripheral states/entities such as Iceland.

Following the Reformation the power of the Danish crown increased steadily and, in 1602, a Danish trade monopoly was established over Iceland in an effort to exclude all foreigners (i.e. non-Danes) from trading in Iceland and secure the profits from the Iceland trade for the crown. Historically, this period has been viewed as a sort of 'dark age' in Icelandic history. Apart from the establishment of the monopoly trade, the $17^{\text {th }}$ century saw several events that marked it as a gloomy period for Iceland; these included the 'Turkish Raid' (1627) and the establishment of absolute monarchy in 1662. The climate deteriorated and natural disasters also became more frequent than in the previous centuries, causing periods of famine and extreme difficulties. However, the bulk of the $17^{\text {th }}$ century was nonetheless relatively benign for Icelandic agriculture and fisheries (Porláksson 2004, 8), and unauthorized trade with merchants and fishermen, mostly from England and Germany, but also Holland, France and Spain (the Basques) alongside the monopoly trade, was lively. The $18^{\text {th }}$ century was similarly a time of immense contrasts as the century saw some of the worst disasters that Iceland has had to endure, as well as the beginning of optimism and 'future-oriented thinking' for the society, influenced by the Enlightenment (Karlsson 2000, 177). 
At the start of the period under study, the Danish kingdom was a force to be reckoned with in the power struggles between European kingdoms. However, in the $17^{\text {th }}$ and $18^{\text {th }}$ century it lost ground to other European nations and by the end of the Napoleonic wars, Denmark's position had changed from being a strong European power into a relatively peripheral small country in Europe. Denmark was forced to cede Norway to Sweden, which in effect reduced the population of the Danish kingdom by 35 per cent, causing a depression that affected all the remaining subjects within the kingdom. Denmark's weakened geopolitical position inevitably had consequences for Iceland. Its capabilities in the North Atlantic had been reduced, which translated into a weaker presence in Iceland, causing Icelanders to seek closer ties with Britain in areas where Danish shelter was no longer sufficient.

In the following sections of this paper, we will first outline the shelter theory - the theoretical framework that this project is based upon. Then we will explore the individual areas of shelter specified by the theory - economic, political and societal shelter - and apply them to the case of Iceland in the period under study. Lastly, the concluding part will summarize the main findings of the paper.

\section{Theoretical framework}

In a way, the shelter theory (see Thorhallsson 2011) is an attempt to bring together a number of important insights from other International-Relations (IR) and small-state theories, each of which we have found inadequate on their own. The aim is to develop a coherent theoretical framework that is sufficiently general to say something useful about the relationship of small entities with the outside world through the ages, without inflicting too much violence on the historical record. It is our contention that in spite of the enormous changes that international relations, and the social institutions that conduct them, have undergone, there is still an identifiable pattern to the relations of small social entities with the outside world: namely, their need for external shelter.

Arguably, the shelter theory can be most directly related to the literature of historical sociology which came to prominence in IR after the sudden end of the Cold War and has been defined as "the study of large-scale social and historical change" which "[seeks] to reveal patterns and structures in human history" (Hobden 1998: 2). In order to reveal such patterns and structures, historical sociology deliberately distances itself from "high-profile contemporary events" and instead looks at the "longue durée" (Linklater 2013: 138). The idea is that many important social structures only become visible when we view them in a long-term historical light. When seen through the lenses of more positivistic or "ahistorical" theories like neorealism, such structures often fade into the background of the analysis because they are simply taken for granted (Cox 1981: 129-131). The shelter theory fits well into historical sociology literature with its focus on the patterns of small-state behaviour through the centuries. As with historical sociology, the idea behind the shelter theory is to look behind the surface of political discourse and traditional historiography at any given time and uncover the nature of their actual relations with the outside world. 
Furthermore, in addition to adopting a long-term perspective, the shelter theory also shares other important attributes of historical sociology. Importantly, the shelter theory follows historical sociology in rejecting a clear dichotomy between the domestic and international spheres (commonly found in IR theory) and insisting on an approach that transcends these boundaries by viewing the "social world as a totality" (Hobden 1998: 8). The simplified "black box" view of the state is discarded in favour of a more nuanced approach that looks at states - and other bearers of political power - as complex social institutions that require explanation in themselves. The shelter relationship cannot be reduced to different capabilities of similar units (as realism would claim) but involves a deep penetration of the small state by the larger entity, often with transformative effects on the small state. In other words, the relationship is not limited to the international arena covered by Realist IR theory but, more importantly, it also has consequences for political, economic and social developments in the domestic sphere of the small state.

In its most basic form, the shelter theory claims that small states/entities need external shelter to thrive. Small states are vulnerable in several ways, and their most viable strategy for survival and well-being is to seek political, economic and societal shelter through their engagement with their larger neighbours. A common characteristic of small states is a small domestic market, which makes them highly reliant on imports and exports, and concentrated production, which often results in heavy reliance on one specific export product. This makes the economies of small states more vulnerable to external, as well as internal, shocks, as there are few domestic buffers that can share the burden of an economic setback (Katzenstein 1985). As a result, the theory posits that small states will seek shelter in the international system by aligning themselves with bigger states/entities in an effort to limit the effects of their economic and political vulnerability. Economic shelter may take the form of direct economic assistance, help from an external financial authority, a common market, favourable market access, etc. Political shelter consists of direct and visible diplomatic or military backing in any given time of need by another state or an international organization according to organizational rules and norms (Thorhallsson 2011). An important point to note here is that 'vulnerability' does not refer exclusively to outside threats - important as they may be - but also to the challenges inherent in being a small society. External shelter not only protects small states in the international sphere, but also helps them to overcome some of their domestic limitations, such as the smallness of their economies and their lack of indigenous knowledge. External shelter enables small societies to reach their maximum potential by connecting them economically and socially to the outside world, while at the same time sheltering them in the turmoil of global affairs. The shelter theory provides us with a useful framework in which to analyse the various aspects of small states' external relations and the strategies they pursue.

Small-state theory has traditionally viewed the vulnerability of small states primarily in terms of economic and political elements. However, we have found that the social and cultural relationship of the small state with the outside world is an element that has been neglected in previous research and its importance for a small peripheral entity such 
as Iceland is hard to over-emphasise. Through social relations - and what we would like to call societal shelter - Iceland, as a peripheral outpost in Europe, managed to avoid isolation by maintaining constant cultural relations with Europe's centre; it sought acknowledgement through these relations and was part of the cultural and ideological developments on the Continent. Relations with the outside world are essential for the development of any society, since it is through constant interaction with other cultures, ideas and ideologies that a society evolves and moves forward. This is especially important for a small and insular society such as Iceland - it relies on cultural relations to avoid isolation and social stagnation and to make up for its lack of indigenous knowledge (see, for instance, Rokkan \& Urwin 1983).

It is important to bear in mind that the shelter that the small state receives may involve various costs and the small state may be forced to pay a certain price for it. However, this price may never be higher than the gains it receives: otherwise one cannot refer to this as shelter. It is also important to bear in mind that the Icelandic society in the period under study was fragmented and split into groups that each had different interests. Foreign influences had different effects on each group. What was beneficial for the elite was not necessarily beneficial for the ordinary farmers in the country, and vice versa. It is thus important to define clearly what is meant with the usage of term 'shelter'. It must be reserved for something that had positive effects on Icelandic society, and the effects must have been positive for the majority of the society. For example, one cannot claim that an act or an event stemming from foreign influences was a form of shelter if it was only beneficial for the elite. If this were the case, one could find shelter in almost any situation, as there are always some groups within societies that profit from any given circumstances, no matter how terrible they may seem to be. Thus, in order for the shelter concept not to become a tautology we have to claim that shelter has to apply to the majority of the people and, thus, be beneficial for society as a whole.

The present paper continues to explore the way in which Iceland's foreign relations evolved throughout its history, and how they affected Icelandic society at large. It shows that Iceland paid a high cost for the economic policy that the Danish crown pursued in the period, which further supports the claim made in the previous paper that there can be a trade-off between economic and political shelter for the small state (Pórhallsson and Kristinsson 2013). A stronger political presence in Iceland resulted in a more regulated economic policy that blocked much of the trade Icelanders had conducted with merchants from the Continent. These policies were in line with ideological currents on the Continent and the paper indicates that in all aspects of society Iceland followed similar trends as other European nations.

\section{Economic shelter}

The Danish crown increasingly sought full control over fisheries and commercial activities in Iceland following the Reformation (Porláksson 2003, 142-151). Originally, it had supported German merchants in gaining control over Icelandic trade in an effort to force English merchants away from the island at the end of the $15^{\text {th }}$ century. In 1490 the 


\section{STJÓRNSÝSLA}

king reinstated laws that prohibited the winter dwelling of foreigners in the country and in 1545 all possessions of foreigners in Iceland were declared to be crown possessions henceforth (Dorsteinsson 1976, 104-105).

However, these efforts made by the king caused only a brief halt in the activities of foreigners in Iceland. English fishermen continued fishing in Icelandic waters and German merchants were active in buying up trading rights and thus continued to dominate trade in the island. The main change brought by the increased Danish presence was that after 1562, the king leased individual harbours to merchants and thus, the crown now gained a handsome profit from the Iceland trade (Porláksson 2003, 142-151). The inability of the Danish crown to provide Iceland with economic shelter is manifested in the fact that the king had initially tried to lease the harbours to the Copenhagen city council. However, the city did not have the capacity to maintain trade in Iceland and the king was thus forced to lease trading rights to German merchants and allow them to continue their trading activities in Iceland (Friðriksson and Dór 2013).

Icelanders increasingly depended on foreign trade for some important commodities, such as grain, timber, iron and metals, cloth and clothing, fishing gear and also some luxury products (Aðils 1919, 436-473; Porláksson 2003, 142-151). Foreign trade had increased considerably in the $16^{\text {th }}$ century and in the process Icelanders had lost the knowledge and skills of how to make salt and grow corn, and also how to use mýrarrauði (bog iron) to process metal for various products (Porláksson 2003, 37; Porláksson 2004, 63; Gunnarsson 1987, 256). This was mainly due to the fact that as foreign trade increased, the need to make these products domestically declined and Icelanders were able to focus on making products that gave them more profit in barter with foreign merchants, such as fish, meat and woollen cloth.

At the end of the $16^{\text {th }}$ century, trading activities in Iceland were livelier than ever before. The King had decided to lease individual harbours to the highest bidder, and German merchants were eager to lease these harbours and benefit from the trade. After 1580, demand increased significantly and merchants started to ask for permission to sail to new harbours that had previously not been in use. Merchants visited 40-50 harbours in Iceland - the largest number of active harbours in any period in Iceland's history and, for the first time, competition between them emerged in some places (Porláksson 2003, 146-149).

In the 1580s, English fishing vessels returned in large numbers to Iceland, after a brief halt in the middle of the century, and a new period of lively relations between Icelanders and English fishermen and merchants began (Porláksson 1999; Agnarsdóttir 2000). English merchants were no longer stationed in Iceland, but instead came with the fishing vessels in the spring, conducted their business over the summer, and left in the autumn. Icelanders were hired as fishermen on English boats, and also to cure the fish once it had been caught. The work was done in exchange for some imported goods, such as timber, nails and fishing equipment. Thus, the arrival of English vessels and the unauthorised commerce they pursued were important for the Icelandic economy, not only because of the employment provided, but also because it gave Icelanders the 
opportunity to catch fish at the height of the fishing season, instead of waiting for the Danish/German merchants to arrive in the summer (Porláksson 2003, 152-161). The products that the English fishermen provided were often in short supply and badly needed during the fishing season, because the height of the season was in the spring (March - April), while the merchants who owned the exclusive rights to trade did not arrive until after the season ended, in May and June (Porláksson 2004).

In 1602, in line with a new European economic policy, the king introduced monopoly trade in Iceland for merchants of the Danish kingdom, under which merchants from Copenhagen, Malmo and Elsinore acquired exclusive rights to the Icelandic trade. The king leased the harbours to Danish citizens rather than Germans in an attempt to secure the benefits of the trade for his own citizens (Lovsamling for Island 1853, 139). However, this did not go as planned, as the Danish merchants still lacked the capacity to sail to Iceland and provide the necessary goods and were therefore forced to deal with the German merchants who possessed the expertise and ships needed. Consequently, the new Danish merchants were in effect only puppets for the Germans, who continued to be important in Icelandic trade (Gunnarsson 1987, 77; Porláksson 2003, 310-313; Friðriksson and Dór 2013, 148).

It was not until 1616 that all trade with non-Danes was prohibited. However, the Danish merchants still lacked the capabilities and experience to maintain proper trading activities, and thus disagreements arose and Icelanders complained to the king about the new commercial arrangement, frequently calling for the abolition of monopoly trade and permission for German merchants to trade again, as they had provided better merchandise, more frequent services, and had sailed to more harbours than the monopoly trade merchants (Aðils 1919, 67-85). The king's response, however, was to tighten the trade monopoly further; he refused to extend the trading permits for merchants who had to rely on Germans for their trading activities. Finally, in 1620, a new arrangement was introduced by which the Danish monopoly was fully secured and the king took full control over the trade. A commercial company, the Icelandic Trading Company, was to oversee the Icelandic trade. This was to become one of the most profitable companies in Copenhagen (Porláksson 1979; Friðriksson and Pór 2013; Porláksson 2003).

Even though the king had forced German merchants out of the Iceland trade the links between Iceland and the German cities, especially Hamburg, would remain intact for the whole of the monopoly trade era. The Danish merchants would maintain trade relations with merchant guilds in Hamburg who bought the Icelandic fish and transported it further south to the Continent. Danish merchants were in reality unnecessary middlemen in the trade between Icelanders and the Hamburg merchants taking a large part of profit. The monopoly trade hindered the direct access of Hamburg merchants to Iceland and allowed the Danish merchants to acquire this position (Gunnarsson 2004).

The Icelandic elite had its say in the establishment of the trade monopoly. Representatives were sent to a meeting with royal officials and the final arrangement was of substantial benefit to the elite. The status quo of the society had been secured. Agriculture was established as the main industry in Iceland, at the expense of fisheries, 


\section{STJÓRNSÝSLA}

and the relatively low price of imported goods benefitted the elite (Gunnarsson 1987, 16-17; Porsteinsson and Jónsson 1991, 213). The price system of the monopoly trade was based on fixed prices which remained mostly unchanged for 160 years. This system favoured the agricultural sector by keeping the price of fish very low - well below world market price - and thus discouraging any investment in the fisheries sector. This ensured that investment and technological innovation in fisheries became impossible during the monopoly trade era (Gunnarsson 1983, 12). Furthermore, foreign merchants were forbidden to stay in Iceland during the winter because that might give them the incentive to start their own fishing industry, in which the Icelandic workforce could be tempted to work (Gunnarsson 1987, 38-42). That could drive the price of labour up and so endanger the privileged position of the landowning elite (see, e.g., Eggertsson 2007, 125-156). All this ensured that fisheries would not become an independent industry in Iceland. The fishing grounds surrounding Iceland were the islands' biggest and most valuable resource - the sector in which Icelanders had a competitive advantage over other nations. The monopoly trade system ensured that this sector could not develop independently, imposing vast social costs on the Icelandic economy. Direct links were established between agriculture and fisheries, where only landowners could utilise the fishing grounds. All labour had to be registered to a farm, thus securing the farmers' control over the labour, and making sure that urban areas based on fisheries, with independent labour, would not develop along the seaside (Eggertsson 2007, 135). Profits from fisheries were used to subsidize agriculture, skewing overall price formation in the economy. This moved the economy away from its most efficient structure and created substantial social costs.

In the $17^{\text {th }}$ century other foreign nations, such as the Dutch, French, Spanish and Basque, increasingly sought to utilize the fishing grounds surrounding Iceland, and conducted unauthorised trade with Icelanders. For instance, in the 1620s, Danish merchants relied on ships from the Netherlands instead of from Hamburg to handle its trade. This connection between Danish and Dutch merchants in the Iceland trade continued until the 1670s (Thomas 1935, 79; Friðriksson and Dór 2013, 232-254). Unauthorised trade was of immense benefit to the Icelanders and even though the king had made such commerce punishable by law, the need for imports (e.g. fishing equipment, grain and salt) was dire and Icelanders continued to utilize the trade opportunities that the foreign fishing vessels brought with them (Aðils 1919, 580). These nations, along with the German and English, would continue to sail to the Icelandic fishing grounds for centuries to come, and trade with Icelanders alongside their fisheries and whale hunting.

Historians acknowledge that in reality the Danish monopoly started in the latter half of the century, rather than at the beginning (Porláksson 2004, 79). In 1684 the king made new efforts to increase his revenues from the Iceland trade. He raised the price of trading rights to merchants and to compensate them for this he allowed an increase in the prices of goods exported to Iceland; thus the merchants could raise their prices (Gunnarsson 1987, 80-81). Furthermore, farmers were now obliged to trade with one specific merchant, and no one else, risking severe punishment if they conducted 
business with anyone other than "their" merchant. More affirmative measures were taken against the unauthorised trade and the activities of foreign ships in Icelandic waters. Merchants were given the right to board foreign ships and confiscate any Icelandic merchandise that might be there; foreign ship-crews were prohibited from having any contact with Icelanders and stricter punishments were enforced (Aðils 1919, 601). Moreover, Icelanders now needed permission from the Danish governor of Iceland if they wished to leave the country, which effectively prevented Icelandic merchants from sailing with Dutch or English ships. These measures were effective, and in the latter half of the $17^{\text {th }}$ century Iceland became much more dependent on Denmark for its imports, as unauthorised trading declined significantly.

The stricter rules against unauthorised commerce and higher prices of imported goods coincided with extremely harsh years at the end of the century, when the fishing industry collapsed and Icelanders had few products to trade for imported merchandise. This resulted in famine and regression of the society (Porláksson 1979, 61). Profits from the Iceland trade were reduced and instead of taking measures to improve the situation in Iceland, the king demanded even higher fees from the merchants (Gunnarsson 1987, 82). Iceland had become increasingly reliant on imports during the previous century. However, the king's policies in this period were in direct opposition to the economic shelter that Icelanders relied on through foreign trade. Prices were raised and whatever competition had existed between merchants was eliminated, to the detriment of Icelandic farmers. The king had finally managed to fully put into practice the policies he had sought to enforce since 1602 and it became abundantly clear that they were not beneficial for the common farmer in Iceland.

At the beginning of the $18^{\text {th }}$ century, the Danish king started to show some interest in improving economic conditions in Iceland following the hardships that the country had endured at end of the $17^{\text {th }}$ century. A committee was established that was supposed to make an assessment of economic and social conditions in Iceland. This committee of two men, Árni Magnússon and Páll Vídalín, was the first sign of a change in Danish policy towards Iceland; they were appointed to investigate and make proposals on all matters concerning administration and the economy of the country (Karlsson 2000, 161). Many proposals were made on what could be done to help the Icelanders, but they were not followed through (Björnsson 2006, 68-70). It can be argued that in the period between 1684 and 1702, Iceland was considered by the king primarily as a source of revenue for the crown, and profits were the most important factor in the Iceland trade. The changes made in 1702 were, most importantly, the lowering of prices back to their pre-1684 levels, and also the extreme punishments to which farmers were subject if they were caught trading with persons other than "their" merchants were relaxed. These changes eased the burdens on the Icelandic population, and the beginning of the $18^{\text {th }}$ century was a much more benign period for the Icelanders (Aðils 1919, 178; Gunnarsson 1987, 241-242).

The Enlightenment reached Denmark in the 1740 s and the middle of the $18^{\text {th }}$ century was a period of economic boom in Denmark. However, this upswing in economic 
conditions did not reach Iceland immediately (Porsteinsson and Jónsson 1991, 235). The Danish attitude towards Iceland and the Iceland trade was changing and in the 1730s two essays were written by scholars in Copenhagen arguing that monopoly trade had "almost destroyed Icelandic industries" (Porláksson 1979, 59-60). The king's policies started to change in line with this view and in 1750, for the first time, an Icelander, Skúli Magnússon, was appointed Secretary General for Economic Affairs (landfógeti), which is indicative of the change in Danish policies towards Iceland. He was the main actor in establishing the first Icelandic industrial company in Reykjavik, which was only a single farm at the time. This industrial company, Innréttingar, was supported by the Danish king and was given the right to trade and conduct business in Iceland, against the wishes of the Danish merchants.

This was an attempt at strengthening and reconstructing the Icelandic economy and is a clear sign of enlightened policies being put into practice in Iceland (Björnsson 1990, 109). The king's policies were in line with the cameralist view that prevailed in Denmark, in which the prosperity of the people and that of the nation went hand in hand (Gustafsson 1990, 44). The crown attempted to establish industries that would stimulate economic growth in Iceland and benefit Icelandic society. The ideology behind this was that prosperity would not only benefit Icelanders, but also the crown, as it would increase its tax revenues. The Danish crown invested a lot of money and gave crown land for various projects which, despite high aspirations, never returned any profit. However, these attempts made by the crown must still be viewed as a major turning-point in its policy towards Iceland, which had up to this point been focused on maximizing profits from the island. In this period the crown started to lose money on Iceland for the first time (Björnsson 2006).

During the periods in the $18^{\text {th }}$ century when the crown had full control of trading in Iceland (Konungsverslun fyrri og sidari) more efforts were made to build up industries and infrastructure. The crown made attempts to establish a competitive fishing industry in Iceland. It wanted the kingdom to receive some benefits from the rich fishing grounds surrounding the country and thus invested substantially in building an industry that could compete with the other European nations that had for centuries utilised these grounds. However, these efforts were met with opposition from the Icelandic elite, which had no desire to change the structure of society by allowing fisheries to become an industry that could compete with agriculture, and the crown gave up its efforts once it realised that it lacked this support. Gísli Gunnarsson $(1983,175)$ points out that in its attempts to modernise the Icelandic economy the crown failed to take into account the domestic situation in Iceland and "the special interests and the prejudices of the ruling indigenous social classes in Iceland were not considered". The crown was attempting to change the productive forces of the society in order to change the socio-economic structure. This was opposed by the ruling elite that had come to rely on the prevailing archaic socio-economic structure for its privileged position and by ensuring that the modes of production within society did not change it ensured that the social structure was maintained (Gunnarsson 1983, 175).

Nevertheless, monopoly trade was abolished in 1787 and replaced by free trade. 
However, this free trade was restricted to merchants coming from areas within the Danish kingdom that were not under monopoly rule themselves, i.e. merchants from the Faroes and Greenland, and "foreigners" from outside the kingdom were still not allowed to trade (Agnarsdóttir 1989, 8). The consequences of this for Icelanders were that the price of exported fish rose dramatically, as its price had been fixed throughout the monopoly trade era (the price more than quadrupled). Furthermore, the price of exported agricultural goods doubled. However, the price of imported goods also rose, but this rise in price was not as great as the rise in the price of exported goods (Björnsson 2006, 262). The result of this was that those Icelanders that traded fish for their imported goods benefited handsomely from this new trading system, alongside other wealthy farmers that had goods to export. However, the poorest part of the population had little to sell for the goods they needed to buy from the merchants, and as a result they only felt the rise in price of imported goods, and considered themselves to be worse off after these changes (Björnsson 2006, 262).

In the beginning, this new trading system appeared to be more beneficial for many Icelanders as they could trade with more merchants and in more places than before. However, eventually the merchants started to complain that this open trade allowed for too much competition between merchants. The administration took their complaints into consideration and the small amount of freedom that existed in the Iceland trade was restricted again by a government decree (Andrésson 1997, Björnsson 2006, 264). These added restrictions came at the same time that the Napoleonic wars were breaking out in the European Continent and the result was that fewer ships and less merchandise came to Iceland. Furthermore, the war spurred inflation on the European Continent that raised the prices of imported goods to Iceland. Icelanders responded by asking for full freedom of trade to the island, but the king refused this request, and even considered it to be an insult to him (Porsteinsson and Jónsson 1991, 259; Björnsson 2006, 266).

As the intensity of the Napoleonic wars grew, it became increasingly difficult for Denmark to maintain shipping to Iceland. Shipments of goods from Denmark became increasingly irregular and the first years of the $19^{\text {th }}$ century were marked by a shortage of imports and higher prices, resulting in death from starvation in extreme cases (Porsteinsson and Jónsson 1991, 260). In 1807 the British fleet bombarded Copenhagen, which lay in ruins afterwards. The ships that had sailed from Iceland to Copenhagen in the autumn were confiscated and ordered to sail to Britain. Iceland's connection with Denmark was in effect severed. Denmark could not maintain its political and economic presence in Iceland as its fleet had been taken over by Britain.

Denmark had lost its fleet to Britain in the war after it sided with Napoleon. Britain had total control over the North Atlantic and confiscated any Danish merchant ships found operating on their trade routes. As a result, Danish merchants were not willing to risk sailing to Iceland. The crown tried to create incentives for merchants to sail by offering various kinds of perks to those who were willing to risk it and also tried itself to provide ships with goods, but these efforts were too small and limited to provide Icelanders with the goods they needed. 


\section{STJÓRNSÝSLA}

Icelandic, and eventually also Danish, officials came to the conclusion that Iceland's survival could only be guaranteed with support from the British government (Agnarsdóttir 2000b, 109). Iceland's Chief Justice, with the help of Joseph Banks, a prominent figure in Britain, was able to convince the British government to allow the captured Icelandic trading ships to continue sailing to Iceland. The official statement was that the Danish dependencies in the North were, for humanitarian reasons, allowed to receive goods from Denmark. Accordingly, English merchants became important providers of goods in Iceland in the years 1807-1815 (see also Andrésson 1997).

In summary, the trade monopoly imposed high social costs on the vast majority of the population in terms of the well-being of the nation and general economic development. The political authority, the Danish crown, centred its policy in Iceland first and foremost on securing the maximum economic benefit. The dominant political and economic ideologies explain the king's lack of concern for his own subjects and why the political authority did not provide Icelanders with economic shelter. Ideological changes were needed before such concern could be felt or shown; when an initiative came from Copenhagen on economic cover for the general public in Iceland, it was blocked by the domestic elite, which still benefited from the old system. On the other hand, Icelanders continued to enjoy partial economic shelter through their unauthorised trade with foreign fishermen and merchants.

\section{Political shelter}

This section will examine whether Iceland's relations with other countries provided direct military and diplomatic backing and shelter through the rules and norms of the international system.

The arrival of Danish naval ships in the Reformation struggle can be considered to signal the arrival of direct political, and military, power in Iceland. The island was by far the most difficult part of the Danish kingdom to reform. Nowhere in the kingdom did the local bishops put up the same amount of resistance (Bregnsbo and Jensen 2004, 122). The opposition shown by Jón Arason, the Catholic bishop of Hólar, against the king signals a struggle between two societal systems. On the one hand, the king represented the arrival of centralized power in Iceland with the modern governance structures that were taking over in Europe. On the other, the bishop of Hólar represented the old feudal system of landowners and peasants (Ísleifsdóttir 1997, 357; Júlíusson 2013, 213). From the viewpoint of the ordinary Icelandic farmer there was no clear difference between the two, but most farmers were not willing to change from the system of feudal protection to a foreign power of which they had no real knowledge (Júlíusson 1998, 104). However, the arrival of centralized power meant that the landowning aristocracy could no longer act according to its own whims, but had to abide by the rules that the king set for the country (Porsteinsson and Jónsson 1991, 198); rules that applied to all citizens. The common farmers were the biggest beneficiaries of the changes that the state power brought. They were able to focus their energy on living an ordinary life instead of constantly being dragged into disputes and conflicts between landlords. Peace 
was established and a society based on the rule of law emerged (Júlíusson 2013, 214; porláksson 2004, 186).

The crown expected to have a monopoly on the use of force in Iceland and asserted its position as the central and single power in the country. Shortly after the Reformation, it had managed to demilitarize Iceland by confiscating weapons in the country through a legal act. The main goal of the act was in all likelihood to eradicate the private armies that had been operated by chieftains and were no longer to be tolerated by the crown. Defences in the country were to be operated by the central power (Helgason 2013, 231239).

Thus, we claim that, in a manner similar to the situation in 1262, Icelanders were shielded from their internal disputes by an external power. The arrival of foreign centralized power into the domestic power structures in the $16^{\text {th }}$ century managed to quell the internal strife that had been a persistent part of Icelandic society and became the basis for the relatively peaceful society that emerged in Iceland after the Reformation and lasted for the next centuries (Júlíusson 2013, 214).

In defence matters, Iceland's peripheral position continued to be its main protection from outside attacks. However, the advancements in shipbuilding in the $16^{\text {th }}$ century meant that sailing to peripheral locations was becoming easier and more ships were able to sail to the North Atlantic and utilize Iceland's fishing grounds. This meant that pirates could now consider Iceland as a destination for their looting and on a few occasions - such as the 'Turkish Raid' of 1627 - Iceland suffered attacks. On the other hand, the country was so sparsely populated with no towns or other dense areas that it was too costly for pirates to sail all the way north to Iceland on their raids (Helgason 2013). The main attraction for pirates was the merchant ships and fishing vessels that sailed to Iceland, as their cargo could often be quite valuable. Therefore, Denmark and England, growing military powers at this time, sent naval vessels to protect their interests in Icelandic waters (Dorláksson 2003, 272; see also Júlíusson 2007; Jóhannesson 1968; Karlsson 2008). Indirectly, this provided the Icelandic population with shelter from further encroachment by other foreign vessels including those of the pirates - though Iceland was more or less defenceless (Porláksson 2004, 172).

It is clear that Denmark sought to protect its interests in Iceland by offering protection for its merchants and the Icelandic population from the growing threat of piracy. When the foreign threat increased, the crown provided weapons and built forts in Vestmannaeyjar and Bessastaðir - which, alongside the fishing harbours on the south-western coast, were the most attractive destinations for plunder (Gunnarsson 1998).

Thus, we claim that what military shelter Iceland did receive at this time came from Denmark and that Icelanders saw Denmark as their main source of military shelter (see, for example, Helgason 2013). However, the effectiveness of this protection can be debated. It is clear that the king did not fully comprehend the vastness of the North Atlantic and the effectiveness of sending one or two ships for protecting Iceland is questionable. Iceland's peripheral geographical position was still the most important factor in its defences. The crown did respond to the threats that arose and increased its 
naval presence in the North Atlantic, but it often lacked the capacity to fully maintain this protection - particularly in times of war on the Continent.

Logically, the increased presence of Danish naval ships in Icelandic waters should have resulted in higher tax burdens on the Icelandic population, as was the case in Norway. In Denmark, and especially in Norway, the tax burden grew dramatically as state power increased (Júlíusson 2007, 5; Lockhart 2007, 222-225). However, the Icelandic elite cited widespread poverty and harsh weather and living conditions as a reason for not being able to pay higher taxes (Lockhart 2007, 225). This argumentation from the Icelandic elite was effective and on many occasions it avoided payments that the king expected to receive from them. Iceland's peripheral location may have played a part in this, since the general policy in Europe in this period was that the more remote a region was from the centre of the kingdom, the lighter were the burdens placed upon it by the central power (Gustafsson 1998). The Icelandic elite could easily have paid higher taxes and did have the capacity to pay taxes at the same rate as Norwegians, but the king seems to have been convinced by their argument that life in Iceland would become impossible if taxes were increased (Júlíusson 2007, 5). Moreover, the Icelandic ruling class refused to provide men for military service. Hence, Iceland did not provide men for the Danish military. On the other hand, Norway had to provide men for military service, which placed a huge burden on its labour reserves (Agnarsdóttir 2008; Júlíusson 2007).

The second element to consider in political shelter is that it is provided by larger states or entities according to the rules and norms of the international community. In the middle of the $16^{\text {th }}$ century a systemic change took place in Iceland with the Reformation. Gradually, the feudal system, based on decentralisation, with landowners and the Catholic Church as the most powerful actors in the society, made way for a centralised power that expected to have a monopoly over the use of force. Violence was no longer tolerated as the main way to settle disputes; instead the crown took over this role. Furthermore the rule of law became more prominent as the powers of the king grew and social status before the law was not as important as it had been. The aristocracy certainly maintained some of its privileges, but a shift towards greater equality took place (Júlíusson 2013; Porláksson 2003, 354-356).

The king set out to restructure his mode of income from Iceland in the aftermath of the Reformation in order to increase his revenues. He took over a part of the taxes that had previously gone to the Catholic Church and consolidated his power over official positions. The episcopal sees kept their landed properties, but the king took over the land owned by monasteries and also that which had belonged to the Catholic bishops as private property. After the Reformation the king owned 19 per cent of all land in Iceland (Dorláksson 2003, 99-107). The position of the elite changed from being associated with military power and land ownership to being based on official positions within the state. In the period from the Reformation and up until the introduction of absolute monarchy in 1662, the new order was a major source of income for the Icelandic elite. The king provided the elite with land and official positions and in turn received higher revenues from his dependency. Legislative powers still remained to a large extent within Iceland, 
where they were exercised jointly by the crown and the Althing (Porsteinsson and Jónsson 1991, 194-195; Porláksson 2003, 223). A new law was passed following the Reformation called the Great Verdict which moved judicial powers in moral issues from the church and made them a secular matter. Similar, actions were taken in other Lutheran countries in Europe at the time. However, this new law was much stricter and more exhaustive in Iceland than the corresponding law in Denmark - the death penalty was introduced for the most serious offences (Karlsson 2000, 135). Icelandic officials were given the power to collect fines from people that broke these laws. This was to become an important source of revenue for the officials and is illustrative of the how the elite became increasingly dependent on the king and the new state power for their wealth and how the state power had taken over the position previously held by the Catholic Church.

State power had come into Icelandic society and set its mark on most of its features; it was beneficial for the Icelandic elite, which consolidated its power and wealth, which were now derived largely from royal patronage. Consequently, the wealth of the elite was to a large extent based on the goodwill and actions of the king. The Reformation had allowed the king to take over a large part of the Catholic Church's possessions and redistribute them to the Icelandic elite, in turn making it dependent on him.

The 150 years following the Reformation were a period of great advantage to the Icelandic elite. The question under scrutiny here is whether the Danish kingdom provided Iceland, i.e. the populace at large, with political shelter. There is no doubt that the Icelandic elite was provided with shelter by the crown. This relationship between king and ruling class was the norm at the time and thus the elite has to be considered a beneficiary of the establishment in Iceland of what had become common system of governance in Northern Europe.

The ordinary Icelandic farmer also benefited from the arrival of a stronger central power. The constant internal struggles that had characterised Icelandic society before the Reformation had been ended and a more peaceful society established. Before the arrival of state power and the changes it brought, disputes were settled by feudal lords based on their strength and position in society. However, after the Reformation, people became more equal in the eyes of the law, even though the elite still held a more prominent position (Kristinsson 2002, 115-116). On a few occasions the king even tried to get the Icelandic elite to ease the burden laid upon the ordinary peasantry in Iceland and, in effect, tried to give them shelter from the elite (Júlíusson 2007, 4). Árni Daníel Júlíusson (2007) claims that the king acted as a patron for the Icelandic peasantry, i.e. that he took over the role that the ruling class and the Catholic Church had played prior to the Reformation, that of a patron in a patron-client relationship. Thus, the crown started to take an interest in the well-being of the Icelandic peasantry and gave it shelter from the levies laid upon it by the elite.

The Icelandic elite had always put great emphasis on retaining the power to appoint officials to positions in order to maintain its monopoly over these valuable positions. The king's powers grew steadily and with the establishment of an absolute monarchy in 1662 he gained monopoly over most aspects of society. The ideology behind absolutism 
was a more just society with a better-functioning administration. Specialisation and division of labour within the administration were introduced and improved its functioning. The power of the Althing had already started to decline before the introduction of the absolute monarchy in 1662 and the king was able to control what he wanted already in the 1620 s and 1630s. However, the Icelandic elite was immensely powerful in the $17^{\text {th }}$ century and managed to postpone many of the changes that the king intended. Nevertheless, in the latter half of the $17^{\text {th }}$ century, persons from the lower ranks of society started to receive official positions from the crown. The appointments of these men were based on education and merit, rather than family origin and nepotism (Porláksson 2003 ; 2004). However, it was not until the 1720 s that the administration started to function properly and at its full capacity (Gustafsson 1990, 44-47). This is not to say that no efforts were made to make public administration better in Iceland in this period, as many reform measures were taken, but they were opposed by the Icelandic elite, which had an interest in maintaining the old social order.

Denmark's position in Europe had changed dramatically in the $17^{\text {th }}$ and $18^{\text {th }}$ century. In this period it took part in many wars on the Continent and more often than not it was on the losing side. Its military might had declined and it had lost much ground to other European nations. Around the middle of the $18^{\text {th }}$ century, Denmark started to change its foreign policy, taking on a more neutral role in Europe (Feldbæk 1983). This policy proved to be very profitable and the latter part of the $18^{\text {th }}$ century was a period of considerable upswing in the Danish economy - affecting Iceland as well. However, in the Napoleonic wars, Denmark was no longer able to hold a neutral status and was dragged into the wars where it was on the losing side. Its fleet was destroyed and yet again it suffered loss of power and land. The decline of Danish power in Europe had serious repercussions for Iceland. England was now in total control over the North Atlantic. It became evident in these years that Denmark no longer had the ability to maintain any form of real presence in Iceland.

In 1808, a privateer ship from England stole the 'Land Register Fund' (the King's revenues) in Bessastaðir. The captain, Thomas Gilpin, claimed that he had sailed to Iceland to break down Danish forts and confiscate all possessions of the Danish crown. However, upon arriving in Iceland he realised that there were neither forts nor weapons in Iceland and he had to settle for the "Land Register Fund" (Agnarsdóttir 1989, 71-84). The following year, a Danish sailor, Jörgen Jörgensen, arriving on a British merchant ship, managed to seize full control over Iceland for a short period. He wanted to draft a constitution for Iceland and make it independent from Denmark. However, what is most important from the viewpoint of this paper is the fact that Denmark had no control over Iceland; there was no political shelter. In peacetime, Britain had respected Denmark's control over Iceland and kept its distance. However, now that they were enemy states this was no longer the case, and British ships could more or less act according to their will in Iceland; Iceland was defenceless.

These incidents were the work of men on private ships who were acting against the will of the British government and were put on trial in England when they returned. The 
British government, at the request of the Icelanders, allowed commercial ships to sail to Iceland and in 1810 issued a public announcement saying that the Danish dependencies in the North Atlantic were to be considered neutral in the war and should have friendly relations with Britain. Free trade between Britain and the Danish dependencies was reestablished, which secured the shipment of goods to Iceland, and the inhabitants of these dependencies were under no circumstances to be considered enemies of Britain on their travels, by land or sea (Agnarsdóttir 2008b, 91-94). Thus, Britain came to the rescue of Iceland and offered it both diplomatic and economic shelter in these troubled times. Iceland was still part of the Danish kingdom, but was under the protection of Britain, and continued to be so until the end of the Napoleonic wars.

In summary, Danish political shelter took three forms in the period under study. Firstly, the Danish navy partially protected Icelandic waters. This helped to ensure shipping contact and shield the populace from attacks by pirates. Secondly, centralization, with increased power of the king, provided internal order and political stability. Thirdly, the king made citizens more equal before the law, which guaranteed peasants and the underprivileged greater justice, though he made sure that the domestic elite maintained some of its privileges. Accordingly, the last two points indicate that Iceland followed the rules and norms of the international (European) community. Icelandic society slowly became more just, with a better-functioning administration. However, Denmark was often in financial difficulty and, at the end of the period, was in decline. Hence, despite its willingness, it was often difficult for it to provide its remote island with political cover. The geographical remoteness of the island was still the most important guarantor of its safety.

\section{Societal shelter}

With the Reformation and the consequent strengthening of Danish political power, Iceland's formal connection with the outside world became narrower in scope, compared with the English and German periods. Increasingly, Copenhagen became the cultural capital of Iceland, a position it would hold for centuries to come - it became Iceland's window to the outside world. Those that travelled abroad went to Copenhagen; most of them stopping there - at least for the winter - and the very few that travelled further came in contact with the city before moving on. This was the place where Icelanders learned about new ideas and innovations from the Continent; where new ideologies and cultural currents were introduced to them; and where they came in contact with people from other parts of the world (Friðriksson and Pór 2013, 320). Most Icelanders who travelled to Copenhagen came back to Iceland, bringing with them these new ideas that spread throughout the country and became part of Icelandic culture. It is hard to overstate the importance of these cultural relations for the development of Icelandic society. Accordingly, despite its peripheral location, Iceland enjoyed considerable societal shelter provided by Denmark and manifested in fields such as education, health care, social policies and the enforcement of law and order. This section will examine aspects of these relations and how they benefited Icelanders. 
The Reformation ended Iceland's relations with the Roman Catholic world. Iceland was following the same trend as its closest neighbours. However, due to its peripheral position and narrow relations with the outside world, this shift was perhaps more absolute in Iceland than in other parts of Northern Europe. The Reformation was not only a religious movement that swept through the region: it brought with it changes in secular as well as in spiritual life. It was a continuation of the Renaissance and Humanistic movements that had developed in Europe in and after the $15^{\text {th }}$ century and spurred changes in cultural and intellectual life in Iceland. There was a renewed interest in Iceland's cultural past and an increased emphasis was placed on education. The cultural upheaval caused by the Reformation was the prerequisite for the progress made within the society in the following centuries (Júlíusson and Ísberg 2005, 120-125). Iceland benefited from this, as can be seen by the increase in research and thirst for knowledge in the $16^{\text {th }}$ and $17^{\text {th }}$ centuries.

It is often difficult to make a clear distinction as to whether foreign influences in Iceland came from Denmark or from other parts of Europe in this period, as almost all of Iceland's relations with the outside world were channelled through Copenhagen (Friðriksson and Dór 2013, 103). In the $18^{\text {th }}$ century, Icelanders were introduced to the new cultural currents on the Continent, with both Pietism and the Enlightenment entering Iceland around the middle of the century. Both these movements had come to Denmark from Germany and were introduced in Iceland relatively late, compared to other European countries. However, they were both important for the progress of Icelandic society in the $18^{\text {th }}$ century. Pietism is most visual in the work of Ludvig Harboe in Iceland. He was sent by the Danish authorities to examine and assess the state of religious life and the standard of education in Iceland. The most lasting effect of his work is the policy he formed in promoting general literacy in the country which had a lasting effect (Karlsson 2000, 169-172). The Enlightenment affected Icelandic society and culture in numerous ways - in education, culture and administration (Júlíusson and Ísberg 2005, 178-179). It was the ideological reason behind the attempts made by the Danish government to improve living standards in Iceland. Ingi Sigurðsson $(1990,26)$ argues that at no point during Danish administration of Iceland did the crown show as much initiative on reform in Iceland as it did in the $18^{\text {th }}$ century. Reforms were being made in the Danish administration and the idea was to increase general welfare so as to raise the state's tax revenues, to the benefit of all parties. This was achieved through direct government initiatives and by making the administration more efficient. This policy, called cameralism, was introduced into Denmark from Germany. It started with the absolute rulers in the $17^{\text {th }}$ century, but reached its peak with the Enlightenment in the mid- $18^{\text {th }}$ century (Gustafsson 1990). Also, judicial reforms were initiated by which punishments for crimes were made less severe, and the death penalty was abolished in many cases (Björgvinsson 1990; Björnsson 2006, 173-174). Thus, the judicial system can be said to have been made more humane. These changes were in line with the ideological currents in Europe at the time. Denmark made changes according to these policies in the $17^{\text {th }}$ and $18^{\text {th }}$ century and tried to include Iceland in them as well. 


\section{STJÓRNMÁL \& \\ STJÓRNSÝSLA}

Being part of the cultural and ideological trends in Europe was important for a peripheral entity such as Iceland. Through these contacts with the European centre, the inhabitants of the island acquired new knowledge and learned of new ideas that they were then able to incorporate into their own culture. This in turn helped Icelanders to maintain contact with the centre and allowed them to develop in a similar manner. These were not necessarily all positive influences - the persecution of people for witchcraft perhaps being the most obvious example of the contrary - but they kept Iceland in contact with developments that were taking place in Europe and made sure the peripheral island would not become an isolated island. They were the prerequisites for progress in Icelandic society and the flourishing of its cultural life, and in that sense they provided Iceland with an important societal shelter. In the rest of the section, we will look at more specific aspects of this shelter provided by the Danish kingdom.

Denmark provided Iceland with a clear beneficial shelter in educational matters, particularly higher education. The monasteries and the episcopal sees had been centres of learning and scholarly activity, but until the Reformation there was very little dayto-day schooling and very few people had the opportunity to pursue higher education (Guðmundsson 2000, 171-174; Porsteinsson and Grímsdóttir 1990, 141-145). By the beginning of the $16^{\text {th }}$ century, Iceland had started to lag behind other European countries in educational matters. The establishment of universities in Europe (for example Copenhagen in 1479 and Uppsala in 1477) had increased education in these countries and moved it out of the hands of the Catholic Church, while Iceland was still somewhat stagnant in these matters (Bjarnadottir 2006, 30). Following the Reformation, the monasteries and convents, the learning centres of the country, were dissolved. However, the Reformation did not terminate education in Iceland. The crown re-established schools at the episcopal sees, with a curriculum that suited the new doctrine. It was important for the king that the population in Iceland would learn about the new doctrine, and not only in order to strengthen his power over the country: it was important that his subjects subscribe to the same belief system as the welfare and prosperity of the kingdom was based on - the pious and God-fearing life of his subjects - in all parts of the kingdom (Friðriksson and Dór 2013, 104). In Catholic times, education had been a privilege reserved for the elite, but the new schools (though few in number) offered free admission, and free board and lodging, for poor students (Porláksson 2003, 380). Thus, the Reformation broadened the access to education and made it possible for the poorer part of the population to pursue it.

Icelanders had always had to seek higher education in Europe, as there were no universities in Iceland. In 1579, the king decided that Icelandic students should enjoy certain privileges in their studies at the University of Copenhagen. They enjoyed priority access to free board and lodging, which was awarded for the first five years of their studies at the university. The argument for this support was that because of their poverty, very few Icelanders came to study in Denmark and that something had to be done to increase the number of educated Icelanders (Björnsson 2006, 113). This support was also given to students from Norway and the Faroe Islands, and poor students from Den- 
mark, for some time, but Icelanders were beneficiaries of this for much longer, i.e. until 1918 (Agnarsdottir 2008, 72-73; Porláksson 2003, 382-384; Karlsson 2008, 159). As a result, the University of Copenhagen was, more or less, the only institution in which Icelanders pursued higher education from around 1600 until 1918. The number of Icelandic students was not great in our period - only around two per year on average - but they had considerable effect in Iceland (altogether, about 500 Icelandic studies studied at the University from 1540 to 1800). The University had become the place where Icelanders came into contact with the outside world; where they acquired new knowledge and innovative ideas; and where they were introduced to foreign cultural currents which they brought back with them to Iceland (Friðriksson and Dór 2013, 341).

What were the benefits for the Danish kingdom in focusing so highly on education and awarding such privileges to Icelanders? Helgi Dorláksson $(2003,382)$ sees this in terms of religious orthodoxy and the emphasis that the Danish king put on giving the 'right' education to all priests within his kingdom. Iceland lacked a clergy trained in the new doctrine and it was important to the king that they receive their education within the kingdom and not in other places in Europe - such as Germany, Britain or Holland - in order to maintain control over their teachings (see also Friðriksson and Pór 2013, 344). However, one can also speculate as to whether this privilege can be related to the remoteness of Iceland and the difficulty that the king had experienced in maintaining his power and position in the country. Through education, he could inculcate doctrines into the educated elite of the country and thus promote a certain mode of thinking in Iceland. This could make the population more loyal to the crown and reduce the importance of maintaining a physical presence in the country to maintain law and order. In the $18^{\text {th }}$ century, it became a requirement for officials in Iceland to have a law degree from the University of Copenhagen (Gustafsson 1994, 128). This resulted in a bettereducated administration, but was also a way of strengthening ties between the Icelandic elite and the crown. Thus, the king offered Icelanders easier access to education that would in turn benefit the crown and the Icelanders themselves through them having better-educated and better-informed administration and clerics.

It was not only academic studies that Icelanders could pursue in Copenhagen: many Icelanders sailed to Copenhagen to learn various crafts. These students were also supported generously by the Danish government, which allowed them to live a decent life. This support was severely criticized by Danish students at the time, since they did not receive the same benefits and therefore saw it as discrimination against them (Björnsson 2006, 114). There are records of Icelanders in Copenhagen studying to become, for example, gold- and silversmiths, watchmakers, carpenters, blacksmiths, printers, tailors and ship-builders (Friðriksson and Pór 2013, 403-411). Some of these would stay in Copenhagen, where they plied their trades in the city, but others travelled back to Iceland, bringing with them the skills they had acquired. The general level of education in Iceland was high compared to other parts of the kingdom, which can be directly attributed to the king's educational policies towards Iceland (Gustafsson 1985). This policy gave Icelanders an opportunity they would certainly not have enjoyed otherwise and created a 
more educated population, which from the perspective of our times must be considered as a form of shelter provided to Icelanders by Denmark.

Furthermore, importantly, the University of Copenhagen was the centre for Icelandic studies in the world and Copenhagen was the place where Iceland's cultural heritage was preserved. The crown was quite liberal in its policies towards the dependency in the North and Iceland's ancient culture was highly respected in the kingdom - especially from the $18^{\text {th }}$ century and onwards. Iceland was allowed to use its own language in governance and in the church, and Icelanders could write letters to the king in Icelandic with their complaints and other issues, and thus be heard in their own language (Agnarsdóttir 2008). The kingdom pursued a policy of preserving the Icelandic cultural heritage, by collecting old manuscripts and supporting research in the field. The manuscripts were not considered to be purely Icelandic, but to be part of the common Nordic cultural heritage as they contained the history of the Nordic kingdoms. The king, the nobility and scholars hired Icelandic students to study and work on the manuscripts and in return they received food, accommodation and payment (Friðriksson and Dór 2013, 332). This interest in Nordic and Icelandic culture was the largest single contributory factor in the preservation of Icelandic manuscripts, literature and the preservation of the language.

With the Reformation, a central authority took over the societal functions previously executed by the Church. Law and order was established and social institutions that today are seen as fundamental parts of a functioning society, such as schools and hospitals, were put under the control of the state. The transition has been described as having been harsh on the most vulnerable parts of society - the poor, sick, and the elderly - especially considering the social-security functions of the monasteries (Ísleifsdóttir 1997, 311-312). However, Helgi Dorláksson (2003, 126-128) points out that the same system existed before and after the Reformation regarding support for the poor and needy with the exception of the monasteries. This was a system that had existed for centuries and was based on communal obligations that the better-off farmers were expected to discharge in order to help people from the most vulnerable part of society (Porláksson $2003,127)$. However, there is an ongoing debate amongst historians on whether or not more resources were spent on this system after the Reformation (e.g. Porláksson 2003, 127; Ísleifsdóttir 1997; Guttormsson and Kjartansson 2014).

These changes were a part of the same trend that was taking place elsewhere in Protestant Europe. Monasteries were closed down and their obligations were taken over by the state. The difference, however, between Iceland and many other parts of the kingdom - especially those close to the centre - was that in Iceland there was no bourgeoisie to take on the responsibilities of running the new state-owned institutions (Ísleifsdóttir 1997, 311). The crown seems to have taken the view that the old system of communal obligations was sufficient, and maintained this policy even though Iceland sought to have hospitals established on several occasions in the $16^{\text {th }}$ century. In the $17^{\text {th }}$ century, the governor of Iceland, Henrik Bjelke, tried to persuade the crown to build four shelters that were to provide the functions provided by monasteries in Catholic times, i.e. as sanctuaries for wandering beggars and leprosy patients, but the idea was blocked by 
the Icelandic elite, mostly because it was expected to provide funds to run the hospitals (Porláksson 2004, 146-149).

In the $16^{\text {th }}$ and $17^{\text {th }}$ centuries, public health care was of limited concern to monarchs and there was no real sense of obligation for them to provide it. This would not change until the middle of the $18^{\text {th }}$ century, with the Enlightenment, when the state started to take more interest in the lives of ordinary people and became more concerned about their welfare. Jón Ólafur Ísberg $(2005,35)$ claims that the real effects of health care for society up until the Enlightenment were on the whole minuscule, and that it was not until the new world-view and ideas of the Enlightenment merged with the natural sciences of the time that one could see real benefits for the general public. This change in attitude started in Denmark in middle of the $18^{\text {th }}$ century and reached Iceland shortly afterwards. In 1760 the position of Director of Health (landlaknir) was established, with an office near Reykjavik, by the Danish authorities. The director was supposed to be the doctor for Iceland, as well as overseeing education and research in matters concerning health care (Björnsson 2006, 159-164; Ísberg 2005, 62-64). In the years to follow, numerous reforms in health care were introduced in Denmark, applying to Iceland as well. These included laws against ill-trained doctors that were to protect the educated specialists and to ensure that the general public was not cheated. Also, the numbers of doctors' and midwives' positions were increased. Furthermore, the king issued a decree on hospitals, defining proper conditions for patients and how the buildings were to be constructed. All this was in line with developments in Europe and shows that Iceland was influenced by the changes that were taking place on the Continent (Ísberg 2005, 60-69).

In the latter half of the $18^{\text {th }}$ century, health care was a priority within the Danish administration and Iceland benefited from the policy. The main aim was to provide better health care for the whole of the population, and to ensure access to it for everyone; free health care was even available for the poor. The state now saw it as its obligation to attend to the well-being of its citizens. It was only the Icelandic elite that opposed these changes because of the high costs involved for the local communities. However, in the end it was the Danish administration that paid for the bulk of the changes and, thus, was the main driving force behind these improvements (Ísberg 2005, 62). This should not be taken for granted, and in comparison with other peripheral entities, Iceland benefited enormously from the emphasis the Danish kingdom placed on promoting public health care for its citizens at the end of the $18^{\text {th }}$ century and onwards. The kingdom introduced policies that would have a lasting effect on the attitude towards public health care in Iceland. These policies were based on the view that the state should be central in funding, organizing and delivering the health system. This would ensure the best practices and allow open access for people to the services provided. The state provided regulation, legislation, and education and made sure that adequate health care was provided for the general public. These policies were put into practice to the extent that was possible, but domestic opposition and conditions in Iceland often stood in the way (Ísberg 2005, 62).

We see in this period how the monopoly trade narrowed Iceland's window to the outside world and made Denmark more or less the only possible shelter provider for 
Iceland. However, the influence of non-Danish fishermen and 'illegal' merchants is also worth noting. They brought with them news from the Continent and new knowledge that benefited Icelandic society. For instance, they taught Icelanders new techniques and methods of curing fish. They kept farmers who lived in isolated fjords in contact with the outside world and influenced their world-view (Porláksson 2003, 158). In some instances friendships developed between Icelanders and the foreign sailors who came year after year to Icelandic shores. Some Icelanders used this opportunity to travel abroad with the foreign ships to seek education or new opportunities in life that were not readily available in the remote and peripheral communities of Iceland (Porláksson 1999, 258-277). Accordingly, Iceland enjoyed some social cover from engagement with 'foreign' fishermen and merchants, though the Danish Kingdom was the main provider of societal shelter.

\section{Conclusions}

Our findings indicate that there is not necessarily any correlation between political, economic and societal shelter. Interestingly, our case indicates that a small entity can enjoy political and societal cover from a larger entity despite the simultaneous enforcement of an unfavourable economic policy.

The shelter theory needs to draw lessons from findings which indicate that strict political cover by a single external entity may restrict economic freedom and be highly costly. The smaller entity may benefit from looser political ties - at least economically. Closer engagements with several international actors may be more fruitful as long as they do not threaten internal and external security and the entity in question has the capacity to utilise its external relations. Moreover, our findings indicate that the general public is in most danger of suffering economic and 'societal' loss due to the cost of the shelter, while the domestic elite is more likely to find ways of influencing the country's foreign relations in its own favour. The domestic ruling class may, in fact, prevent the shelter provider from making it share its profits with the common man.

The paper's findings are best seen in terms of the three forms of shelter outlined in the shelter theory. Firstly, the Icelandic elite based its position and wealth on its property and the official positions that were granted by the crown. The structure of the monopoly system secured the stagnation of societal structure and was one of the fundamental elements keeping the Icelandic elite in its position. The Icelandic society paid a high price for this economic policy. It was designed to ensure that the reigning social order, which benefited landowners and those in privileged positions, would prevail - at the cost of economic development in the country (Gunnarsson 1987; Eggertsson 2007). The elite, or at least a part of it, benefited from the monopoly arrangement, while the vast majority of Icelanders suffered, economically. Hence, the Danish monopoly cannot be considered as providing economic shelter. It can rather be described as having been highly costly to society at large. On the other hand, and importantly, Icelanders continued to enjoy partial economic cover by their engagement with non-Danish fishermen and merchants. 
Secondly, our findings indicate the importance of societal shelter through external engagement - which was provided mainly by the Danish Kingdom in this period. It is hard to overstate the importance of foreign societal relations with the outside world for a small and peripheral community such as Iceland. It became more peripheral in Europe after the rediscovery of America (Karlsson 2009, 311), as the European Atlantic powers turned their attention to the newly-discovered prosperous lands and the profits they could derive from them. External relations constituted a channel for important knowledge and innovations to enter Icelandic society. A small and scattered society, such as the rural communities in Iceland, is not the ideal soil for the emergence of new knowledge, ideas and innovations. The country benefited enormously from Danish educational, health-care and social policies, especially in the latter half of the period. By being in constant contact with the European Continent through Denmark, Icelandic society was able to be part of the societal, political and economic evolution of Europe. The highly valuable societal shelter provided by Denmark should not be underestimated and, particularly, its role in preserving Iceland's cultural heritage - the foundation of the modern Icelandic state.

Thirdly, the Danish navy ensured partial protection of waters and land, though the geographical remoteness of the island was still the main protection from outside attacks. Also, the centralizing efforts of the crown ensured internal order and greater equality of citizens before the law compared with the previous English and German periods. The Danish authorities' policies towards Iceland followed the current norms in Europe at any given time. On the other hand, despite the willingness of the crown, it was often difficult for it to provide its remote island with political cover. Its weak domestic administration often had to rely on the domestic elite and on foreigners to maintain law and order. However, in the end, Denmark was unable to provide the island with sufficient protection during the Napoleonic wars. The Danish kingdom had declined to that extent that it was unable to provide Iceland with political shelter. Britain was now in full control over the North Atlantic.

\section{Notes}

1 The authors would like to thank the following scholars for valuable comments that helped to improve the paper: Gunnar Karlsson, Helgi Skúli Kjartansson, Dorsteinn Kristinsson, Sverrir Steinsson, Daniel Devine and Jeffrey Cosser.

\section{References}

Aðils, J.J. 1919. Einokunarverslun Dana á Íslandi 1602-1787. Reykjavík: Verzlunarráð Íslands.

Agnarsdóttir, A. 1989. Great Britain and Iceland 1800-1820, PhD Dissertation. London: London School of Economics and Political Science, Department of International History.

Agnarsdóttir, A. 2000. 'Ísland og umheimurinn 1580-1630', Skirnir 174 (haust), 413-430.

Agnarsdóttir, A. 2000b. 'Centre and Periphery in Wartime: Iceland and Denmark during the Napoleonic Wars', in I. Sigurdsson and J. Skaptason (eds.) Aspects of Arctic and Sub-Arctic History. Reykjavik: University of Iceland Press.

Agnarsdóttir, A. 2008. 'The Danish Empire: The Special Case of Iceland', in M.N. Harris and C. Lévai (eds.) Europe and its Empires. Pisa: Plus-Pisa University Press, 59-84. 
Agnarsdóttir, A. 2008b. 'Aldahvörf og umbrotatímar', in S. Líndal and P.H. Árnason (eds.) Saga Íslands IX. Reykjavík: Hið íslenzka bókmenntafélag, 5-161.

Alesina, A. and Spolaore, E. 2003. The Size of Nations. Cambridge: The MIT Press.

Andrésson, S.H. 1997. 'Tilskipun um aukið verslunarfrelsi fyrir Îsland árið 1816 og tildrög hennar', Saga XXXV: $95-135$.

Bjarnadottir, K. 2006. Mathematical Education in Iceland in Historical Context: Socio-Economic Demands and Influences, PhD Dissertation. Roskilde University: IMFUFA and Department of Mathematics and Physics.

Björgvinsson, D.P. 1990. 'Refsilöggjöf og réttarfar í sakamálum', in I. Sigurdsson (ed.) Upplýsingin á Íslandi: Tíu ritgerơir. Reykjavík: Hið íslenzka bókmenntafélag, 61-91.

Björnsson, L. 1990. 'Atvinnumál', in I. Sigurðsson (ed.) Upplýsingin á Íslandi: Tíu ritgerđir. Reykjavík: Hið íslenzka bókmenntafélag.

Björnsson, L. 2006. '18. öldin', in S. Líndal (ed.) Saga Íslands VIII. Reykjavík: Hið íslenzka bókmenntafélag, 5-270.

Bregnsbo, M. and Jensen, K.V. 2004. Det danske imperium: storhed og fald. København: Aschehoug.

Cox, R.F. 1981. 'Social Forces, States and World Orders: Beyond International Relations Theory', Millennium - Journal of International Studies 10(2): 126-155.

Eggertsson, D. 2007. Háskaleg hagkerfi: Takifari og takmarkanir umbóta [íslensk pýðing Árni Óskarsson]. Reykjavík: Hið íslenska bókmenntafélag.

Feldbæk, O. 1983. 'Eighteenth-Century Danish Neutrality: Its Diplomacy, Economics and Law', Scandinavian Journal of History (8): 3-21.

Friðriksson, G. and Dór, J.P. 2013. Kaupmannaböfn sem böfuðborg Íslands, fyrra bindi. Reykjavík: Hið íslenska bókmenntafélag.

Guðmundsson, G.F. 2000. 'Íslenskt samfélag og Rómakirkja', in H. Hugason (ed.) Kristni á Íslandi, II. Bindi. Reykjavík: Alpingi.

Gunnarsson, G. 1983. Monopoly Trade and Economic Stagnation: Studies in the Foreign Trade of Iceland 16021787. Lund: Ekonomisk-historiska föreningen.

Gunnarsson, G. 1987. Upp er bodið Ísaland: Einokunarverslun og islenskt samfélag 1602-1787. [Reykjavík]: Bókaútgáfan Örn og Örlygur.

Gunnarsson, G. 1998. ‘Afkoma og afkomendur meiri háttar fólks 1550-1800’, in G.J. Guðmundsson \& E.K. Björnsson (eds.) Íslenska sögupingið 1997. Rádstefnurit II. Reykjavík: Sagnfræðingastofnun Háskóla Íslands og Sagnfræðingafélag Íslands, 118-132.

Gustafsson, H. 1985. Mellan kung och allmoge: Ämbetsmän, beslutsprocess och inflytande på 1700-talets Island. Stockholm: Almqvist \& Wiksell.

Gustafsson, H. 1990. 'Stjórnsýsla [Gísli Ágúst Gunnlaugsson íslenzkaði]', in I. Sigurðsson (ed.) Upplýsingin á Íslandi. Tiu ritgerdir. Reykjavík: Hið íslenzka bókmenntafélag.

Gustafsson, H. 1994. Political Interaction in the Old Regime: Central Power and Local Society in the EighteenthCentury Nordic States. Lund: Studentlitteratur.

Gustafsson, H. 1998. 'Hugleiðingar um samfélagsgerð Íslendinga á árnýöld’, in G.J. Guðmundsson \& E.K. Björnsson (eds.) Íslenskea sögupingið 1997. Rádstefnurit II. Reykjavík: Sagnfræðingastofnun Háskóla Íslands og Sagnfræðingafélag Íslands.

Guttormsson, L. and Kjartansson, H.S. 2014. 'Siðaskiptin og fátækraframfærsla: athugagreinar í tilefni af nýlegum útleggingum', Saga LII(1): 119-143.

Hobden, S. 1998. International Relations and Historical Sociology: Breaking down boundaries. London: Routledge.

Helgason, P. 2013. Minning og saga í jósi Tyrkjaránsins. Reykjavík: Hugvísindastofnun Háskóla Íslands.

Ísberg, J.Ó. 2005. Lif og lakningar: Íslenske heilbrigðissaga. Reykjavík: Hið íslenska bókmenntafélag.

Ísleifsdóttir, V.A. 1997. Siðbreytingin á Íslandi 1537-1565. Byltingin að ofan. Reykjavík: Hið íslenska bókmenntafélag. 


\section{STJÓRNSÝSLA}

Jóhannesson, K. 1968. 'Dættir úr landvarnarsögu Íslendinga', Saga VI, 122-138.

Júlíusson, Á.D. 1998. 'Valkostir sögunnar. Um landbúnað fyrir 1700 og pjóðfélagspróun á 14.-16. öld', Saga XXXVI, 77-111.

Júlíusson, Á.D. 2007. 'Peasants, aristocracy and state power in Iceland 1400-1650', The CAHD papers 2007-2, available at http://axelkrist.com/CAHD/issue_2.pdf, accessed 8 November 2012.

Júlíusson, Á.D. 2013. Landbunaðarsaga Íslands, 1. bindi: Dúsund ára bandasamfélag 800-1800. Reykjavík: Skrudda.

Júlíusson, Á.D. \& Ísberg, J.Ó. (eds.) 2005. Íslandssagan i máli og myndum. Reykjavík: Mál og menning.

Karlsson, G. 2000. Icelands's 1100 Years: The History of a Marginal Society. Reykjavík: Mál og Menning.

Karlsson, G. 2008. 'Dönsk stjórn á Íslandi, böl eða blessun', Saga XLVI(2): 151-163.

Karlsson, G. 2009. Lifsbjörg Íslendinga frá 10. öld til 16. aldar. Reykjavík: Háskólaútgáfan.

Katzenstein, P.J. 1985. Small States in World Markets. Industrial Policy in Europe. Ithaca and London: Cornell University Press.

Kristinsson, A. 2002. 'Besta öldin og sú versta', in E.H. Halldórsdóttir (ed.) 2. Íslenskea sögupingid 2002. Rádstefnurit I. Reykjavík: Sagnfræðingastofnun Háskóla Íslands, Sagnfræðingafélag Íslands, Sögufélag, 108-120.

Linklater, A. 2013. 'Historical Sociology', in Scott Burchill and Andrew Linklater (eds.) Theories of International Relations. $5^{\text {th }}$ edition. Hampshire: Palgrave Macmillan.

Lovsamling for Island, förste bind. 1853. Samlet og udgivet af Oddgeir Stephensen og Jón Sigurðsson. København.

Lockhart, P.D. 2007. Denmark, 1513 - 1660: The rise and decline of a renaissance monarchy. Oxford; New York: Oxford University Press.

Rokkan, S. \& Urwin D. W. 1983. Economy, Territory, Identity: Politics of West European Peripheries. London: Sage Publications.

Sigurðsson, I. 1990. 'Upplýsingin og áhrif hennar á Íslandi’, in I. Sigurdsson (ed.) Upplýsingin á Íslandi: Tíu ritgerđir. Reykjavík: Hið íslenzka bókmenntafélag, 9-42.

Thomas, M.S. 1935. Onze Ijslandsvaarders in de 17 de en 18de eeuw: Bijdrage tot de geschiedenis van de Nederlandsche handel en visscherij. Amsterdam: N.V. Uitgevers-Maatschappij Rnum.

Thorhallsson, B. 2011. 'Domestic Buffer Versus External Shelter: Viability of Small States in the New Globalised Economy', European Political Science (10): 324-336.

porláksson, H. 1979. 'Economic Centralization. The Icelandic Trade Monopoly', in S. Dyrvik, K. Mykland and J. Oldervoll (eds.) The Satellite State in the 17th and 18th Centuries. Oslo: Universitetsforlaget, 49-62.

Porláksson, H. 1999. Sjórán og siglingar: Ensk-islensk samskipti 1580-1630. Reykjavík: Mál og menning

Porláksson, H. 2003. 'Frá kirkjuvaldi til ríkisvalds', in S. Líndal (ed.) Saga Íslands VI. Reykjavík: Hið íslenzka bókmenntafélag, 3-408.

porláksson, H. 2004. 'Undir einveldi', in S. Líndal (ed.) Saga Íslands VII. Reykjavík: Hið íslenzka bókmenntafélag, 5-211.

Dorsteinsson, B. 1976. Tín Dorskastrí 1415-1976. Reykjavík: Sögufélagið.

Porsteinsson, B. and Grímsdóttir, G.Á. 1990. 'Enska öldin með viðaukum eftir Sigurð Líndal', in S. Líndal (ed.) Saga Íslands V. Reykjavík: Hið íslenzka bókmenntafélag, 1-216.

porsteinsson, B. and Jónsson, B. 1991. Íslandssaga til okkar daga. Reykjavík: Sögufélag.

Dórhallsson, B. 2012. 'Iceland's external affairs in the Middle Ages: The shelter of Norwegian sea power', Stjórnmál og stjórnsýsla 8(1): 5-37.

Pórhallsson, B. and Kristinsson, D. 2013. 'Iceland's External Affairs from 1400 to the Reformation: Anglo-German Economic and Societal Shelter in a Danish Political Vacuum', Stjórnmál og stjórnsýsla 9(1): 113-137. 